\title{
PREDICTION OF 100 METERS SPRINT PERFORMANCE BASED ON FIELD TEST
}

\author{
PREDIÇÃO DO DESEMPENHO EM SPRINT DE 100 METROS A PARTIRDE TESTES DE CAMPO
}

PREDICCIÓN DEL DESEMPEÑO EN SPRINT DE 100 METROS A PARTIR DE TESTS DE CAMPO

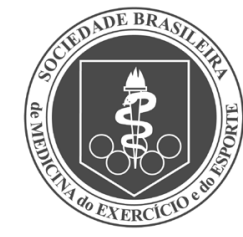

Original Article

Artigo Original Artículo Original
Rodrigo Maciel Andrade1, 1,3,

(Physical Education Professional)

Aylton José Figueira Júnior ${ }^{4}$

(Physical Education Professional)

Alberto Carlos Amadio ${ }^{2}$

(Physical Education Professional)

Júlio Cerca Serrão²

(Physical Education Professional)

1. Universidade Anhembi Morumbi, School of Health Sciences, Sport and Physical Activity Research Group, São Paulo, SP, Brazil. 2. Universidade de São Paulo (USP), School of Physical Education and Sport, Biomechanics Laboratory, São Paulo, SP, Brazil.

3. Universidade de São Paulo (USP), School of Medicine, Laboratory of Movement Study, Department of Orthopedics and Traumatology, São Paulo, SP, Brazil.

4. Universidade São Judas Tadeu (USTJ), Translational Physiology Laboratory, São Paulo, SP, Brazil.

\section{Correspondence:}

Rodrigo Maciel Andrade Av. Prof. Melo Morais, 65, Cidade Universitária, São Paulo, SP, Brazil. 05508-030. rodmaciel@gmail.com

\begin{abstract}
Introduction: The 100-meter dash (100 m) event holds particular appeal. Coaches and researchers seek to understand the determinants of performance in this task. Although information has been produced over the years, it is not fully applied by coaches who generally assess the success of employed training methods through objective field tests, such as $60 \mathrm{~m}$ dash test performance. Objective: Investigate $100 \mathrm{~m}$ performance based on $60 \mathrm{~m}$ performance. Methods: Two hundred and forty six men and 153 women divided into two subgroups were evaluated for estimation ( $F_{\text {validation; }} n=123$ and $\left.M_{\text {validation; }} n=204\right)$ and validation of predictive models $\left(F_{\text {cross-validation; }}\right.$ $n=30$ and $M_{\text {cross-validation; }} n=42$ ) for $100 \mathrm{~m}$ dash performance (time take to cover $100 \mathrm{~m}$ ). Partial time was measured based on the $100 \mathrm{~m}$ distance marked previously every 10 meters from the starting line on both sides of the track. The predictive models were based on the interval in the 60 meters with a time interval of 10-10 m. Results: Magnitude of correlation was very high. High coefficients of determination and differences of no statistical significance ( $p<.001$ ) were found between the criteria and predicted values. The predictive equations presented constant error values below $0.001 \mathrm{~s}$; total absolute error of $0.12 \mathrm{~s} ; 0.10$ sor $^{\mathrm{M}_{\text {validation }}}$ and $\mathrm{F}_{\text {validation, }}$, respectively, and $1.13 \%$ and $0.85 \%$ of total relative error for $\mathrm{M}_{\text {validation }}$ and $\mathrm{F}_{\text {validation, }}$ respectively. Bland-Altman analysis showed an increase in the level of concordance between the criteria and predicted values of $F_{\text {validation }}$ and $M_{\text {validation. }}$. Similar responses were found when the proposed models were applied to $\mathrm{F}_{\text {cross-validation }}$ and $\mathrm{M}_{\text {cross-validation. }}$. Conclusion: The estimation models were able to accurately predict $100 \mathrm{~m}$ performance based on $60 \mathrm{~m}$ performance. Level of evidence: Il; Diagnostic studies - Investigating a diagnostic test.
\end{abstract}

Keywords: Running; Athletic performance; Biomechanical phenomena.

\section{RESUMO}

Introdução: A prova de 100 metros rasos (100 m) apresenta um apelo especial. Treinadores e pesquisadores buscam compreender os determinantes do desempenho nessa tarefa. Embora informações tenham sido desenvolvidas ao longo dos anos, elas não são completamente aplicadas pelos treinadores que, em geral, avaliam o sucesso dos métodos de treinamento empregados por meio de testes de campo objetivos, como o desempenho no teste de $60 \mathrm{~m}$ rasos. Objetivo: Investigar o desempenho de $100 \mathrm{~m}$ com base no desempenho de $60 \mathrm{~m}$. Métodos: Duzentos equarenta e seis homens e 153 mulheres, divididos em dois subgrupos, foram avaliados quanto à estimativa ( $F_{\text {validaçäa }} n=123$ e $M_{\text {validaçăa }} n=204$ ) e validação de modelos preditivos ( $F_{\text {validaçäo cruzadai }} n=30$ e $\left.M_{\text {validaçäoc cruzadai }} n=42\right)$ para o desempenho de $100 \mathrm{~m}$ (tempo para percorrer $100 \mathrm{~m}$ ). O tempo parcial foi medido baseado na distância de $100 \mathrm{~m}$ previamente sinalizada a cada 10 metros, a partir da linha de partida em ambos os lados da pista. Os modelos preditivos foram estimados no intervalo nos 60 metros a partir do intervalo de tempo de 10-10m. Resultados: A magnitude da correlação encontrada foi muito alta. Altos coeficientes de determinação e diferenças sem significância estatística $(p<, 001)$ foram encontrados entre os critérios e os valores previstos. As equações preditivas apresentaram valores de erro constantes inferiores a 0,0015; erro total absoluto de 0,125; 0,10s para $M_{\text {validacăo }}$ e $F_{\text {validacäar }}$ respectivamente, e 1,13\% e 0,85\% de erro relativo total para $M_{\text {validaçäo }} F_{\text {validacăa }}$ respectivamente. A análise de Bland-Altman mostrou um aumento no

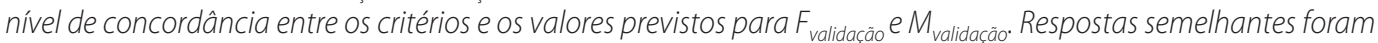

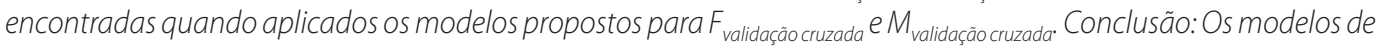
estimativa foram capazes de prever com precisão o desempenho de $100 \mathrm{~m}$ a partir do desempenho no teste de $60 \mathrm{~m}$.

\section{Nível de evidência Il; Estudos diagnósticos - Investigação de um exame para diagnóstico.}

Descritores: Corrida; Desempenho atlético; Fenômenos biomecânicos.

\section{RESUMEN}

Introducción: La prueba de 100 metros rasos (100 m) presenta un apelo especial. Entrenadores e investigadores buscan comprender los determinantes del desempeño en esa tarea. Aunque hayan sido desarrolladas informaciones a lo largo de los años, ellas no son completamente aplicadas por los entrenadores que, en general, evalúan el éxito de los métodos de entrenamiento empleados por medio de tests de campo objetivos, como el desempeño en el test de $60 \mathrm{~m}$ rasos. Objetivo: Investigar el desempeño de $100 \mathrm{~m}$ con base en el desempeño de $60 \mathrm{~m}$. Métodos: Doscientos cuarenta y seis hombres y 153 mujeres, divididos en dos subgrupos, fueron evaluados cuanto a la estimativa ( $F_{\text {validación }}$; $n=123$ y $\left.M_{\text {validación; }} n=204\right)$ y validación de modelos predictivos ( $F_{\text {validación cruzadai }} n=30$ y $\left.M_{\text {validación cruzadai }} n=42\right)$ para el desempeño de $100 \mathrm{~m}$ (tiempo para recorrer $100 \mathrm{~m}$ ). El tiempo parcial fue medido con base en la distancia de $100 \mathrm{~m}$ 
previamente señalizada a cada 10 metros, a partir de la línea de largada en ambos lados de la pista. Los modelos predictivos fueron estimados en el intervalo en los 60 metros a partir del intervalo de tiempo de 10-10m. Resultados: La magnitud de la correlación encontrada fue muy alta. Altos coeficientes de determinación y diferencias sin significancia estadística $(p<, 001)$ fueron encontradas entre los criterios y los valores previstos. Las ecuaciones predictivas presentaron valores de error constantes inferiores a 0,0015; error total absoluto de 0,$125 ; 0,10 s$ para $M_{\text {validación }} y F_{\text {valida- }}$ ción, respectivamente, y $1,13 \%$ y $0,85 \%$ de erro relativo total para $M_{\text {validación }} F_{\text {validación, }}$ respectivamente. El análisis de Bland-Altman mostró un aumento en el nivel de concordancia entre los criterios y los valores previstos para $F_{\text {validación }}$ y $M_{\text {validación. }}$ Respuestas semejantes fueron encontradas cuando aplicados los modelos propuestos para $F_{\text {validación cruzada }}$ y $M_{\text {validación cruzada. }}$ Conclusión: Los modelos de estimativa fueron capaces de prever con precisión el desempeño de 100 $m$ a partir del desempeño en el test de $60 \mathrm{~m}$. Nivel de evidencia ll; Estudios diagnósticos - Investigación de un examen para diagnóstico.

Descriptores: Carrera; Rendimiento atlético; Fenómenos biomecánicos.

\section{INTRODUCTION}

100-meter dash (100m) events arouse great fascination around the world during Olympic Summer Games and World Championships. While the public yearns to know the fastest athlete, coaches and sport scientists seek to understand the determinants of performance in order to potentiate them.

The contribution of the frequency and stride length, ${ }^{1-5}$ flight $^{6}$ and contact time, ${ }^{7}$ proficiency of the stretch-shortening cycle, ${ }^{8}$ vertical ${ }^{5,9}$ and leg stiffness, ${ }^{5}$ maximum vertical force, length change of the lower limbs in step and the oscillation of the mass center ${ }^{4,5}$ have been previously demonstrated to increase speed.

These were based on laboratory tests ${ }^{10}$ and/or low speed variation rate, ${ }^{10}$ conditions of lower ecological validity. As a result, coaches choose to use field objective tests before the need to evaluate the success of training means and methods employed ${ }^{3}$, among them 60-meter sprint in Test Maximal Running Velocity $(60 \mathrm{~m}) .^{11}$

Even aware of low understanding of the parameters of capacity that contributed to the performance or require adjustments, coaches use as an argument the absence of need for resource utilization, specific equipment and rapid feedback.

However, little is known about the predictive validity of $60 \mathrm{~m}$ test for performance in 100m, which has important practical relevance because if it is considered a monitoring strategy of adaptive responses to training, it can lead to misinformation of the observed phenomenon. And in this condition leading to inadequate adjustment of training strategies, not performance optimization.

It is therefore needed to clarify this validity. With this, the aim of this study was to investigate the predictive performance in $100 \mathrm{~m}$ sprints in male and female athletes, from the performance in $60 \mathrm{~m}$ test.

\section{METHODS}

In order to ensure maximum performance, 100-meter dash FPA Adult Tournament of 2015 and 2016, the official competition of Federação Paulista de Atletismo and Troféu Brasil CAIXA ${ }^{\circledR}$ de Atletismo, official competition of the Brazilian Athletics Confederation were considered. All heats and finals qualifiers of male and female athletes were analyzed ( $n=399$ ). After receiving an explanation of the procedures and risks/benefits of the research, the volunteers signed the informed consent form, approved beforehand by the Ethics Research Committee of the School of Physical Education and Sport of the University of São Paulo (Certificate of Submission for Ethical Appraisal no. 30588014.2.0000.5391, protocol number 030531/2014) with a description of the investigational procedures.

The sample was divided according to sex, male (M; $\mathrm{n=246)}$ and female ( $F ; n=153)$.
Whereas the objective of the present study and the applicability thereof, and when the criterion is to be predicted to some subsequent behavior analysis, the predictive validity becomes the point of greatest concern. ${ }^{12}$ With this in mind, each group was randomly divided into mutually exclusive subsets, used to estimate the parameters [validation $\left(F_{\text {validation }}\right.$ with $n=123$ and $M_{\text {validation }}$ with $\left.n=153\right)$ ] and to cross validate the models [cross-validation ( $F_{\text {cross-validation; }} \mathrm{n}=30$ and $\left.M_{\text {cross-validationi }} \mathrm{n}=42\right)$ ]. The cross-validation subsets exhibited a representative sample size of $20 \%$ of the sample size for sex.

Random Test-and-Train Experiments strategy of cross-validation and Random Subsampling were adopted because these produce results of much applicability and best estimate of errors in studies with similar characteristics to the research herein. ${ }^{12,13}$

Kinematic analysis was performed by the technique frame by frame. Five high acquisition rate cameras (EXILIM ${ }^{\circledR}$ - Cásio) were used at a sampling rate of 240 frames per second (fps).

Although $100^{14}$ and $50 \mathrm{fps}^{15}$ are reported in literature for similar analysis with acceptable error magnitude, ${ }^{15} 240 \mathrm{fps}$ was used in order to obtain greater discretization and minimizing errors in the identification of desired events.

Partial distances of 10 meters were previously flagged from the starting line on both sides of the running track, allowing the quantification of the time interval in which each athlete concluded the distance.

Cameras were fixed in tripods and positioned 12 meters in height relative to the ground, with a distance of 35 meters starting from the outer edge of the lap number eight with 20 meters between each other. The calibration of the collection of each partial volume was performed with 10-cm diameter markers set at known distances.

Despite being compulsory in official sprints to use blocks starting strategy in order to assign ecological validity and therefore, closer proximity to the usually adopted in monitoring and control procedures of the training loads, the moment when the foot touched the ground after the beep-on test was considered to start the timing.

The time interval at which each participant concluded each partial distance of 10 meters to 60 meters long was used for generation of predictive models. To validate the predictive models the sum of all the time slots of each partial measurement was used as the criterion.

The temporal parameters were quantified with Kinovea Video Editor 0.8 .15 software.

After confirmation of adherence to normal distribution of data, descriptive statistics used were the average and standard deviation.

Considering the major changes of the magnitude of time of each partial $10 \mathrm{~m}$ for the development of a predictive model, multivariate 
regression analysis was used. The adequacy of the data to the assumptions was previously checked. ${ }^{16,17}$

The normal distribution of the residues was performed by Kolmogorov-Smirnov test, considering the standardized residuals; homoscedasticity waste was checked by the square of the standard waste of Pesarán-Pesarán and Bartlett sphericity.

The absence of autocorrelation was analyzed by Durbin-Watson test. 17,18 The linearity of the residues was assessed by visual inspection of the scatter plot constructed with standardized predicted values and standardized residuals. ${ }^{17}$ For diagnosis of multicollinearity the quantification criteria of the parameters Variance Inflation Factor (VIF), eigenvalue, incremental percent, condition index was taken. For VIF a value of up to 1 was assumed as absence of collinearity between 1 and 10 with acceptable collinearity $>10$ with collinearity problem; ${ }^{19}$ For eigenvalue and incremental percent, values close to zero, and for condition index, values close to 10 are all indicative of collinearity. ${ }^{16}$

There was still necessary to use the multivariate technique of main components analysis and Ridge Regression Estimator regression analysis. ${ }^{20}$

The Pearson ( $r$ ) and determination $\left(R^{2}\right)^{12,21}$ correlation coefficient, constant error (CE), standard error of measurement (SEM), absolute total error $\left(\mathrm{TE}_{\mathrm{abs}}\right)$ and overall relative error $\left(\mathrm{TE}_{\mathrm{rel}}\right)^{21}$ were calculated.

The correlation coefficients were ranked as trivial $(r<0.1)$, low $(0.1>r<0.29)$, moderate $(0.31>r<.50)$, large $(0.51>r<.70)$, very large $(0.71>r<.90)$, near perfect $(0.91>r<.99)$ and perfect $(r=1){ }^{22}$

Student's t-test for paired samples (t) was used to check for differences between the predicted and criteria values, and Bland-Altman ${ }^{23}$ was conducted to verify the agreement between the predicted and criteria values, including the limits of agreement at 0.95\%.

Whereas the estimated regression coefficients can vary from one sample to another when the independent variables are correlated (multicollinearity) with inaccuracy of the predicted value, ${ }^{24}$ we investigated the possibility of extrapolating models proposed to another context (cross-validation). ${ }^{12,19}$

The values of $r, R^{2}, t, C E, S E M, T E_{a b s}, T E_{r e l}$ and Bland-Altman analysis ${ }^{23}$ were also carried out for cross-validation analysis.

The NCSS ${ }^{\circledR}$ (NCSS LLC; USA) and SPSS ${ }^{\circledR}$ (SPSS Inc, USA) softwares were used. The significance level equivalent to a Type I error was $0.5 \%$.

\section{RESULTS}

Analysis of the standardized residuals showed values of $p=0.94$ and $p=0.58$ for $F$ and $M$, respectively, given the normal distribution assumption. This response is similar to the square analysis of standardized residuals ( $p=0.31$ and $p=0.97$ for $F$ and $M$, respectively) and sphericity test $(p<0.001)$.

Durbin-Watson test ${ }^{18}$ indicated the absence of autocorrelation from the chosen confidence level ( $p<.05)$, sample size (by sex) and number of independent variables. Visual inspection of the dispersion graph between standardized predicted value and standardized residual value showed randomly dispersed distribution around zero, then linearity and homoscedasticity. ${ }^{17}$

Given the eigenvalue, incremenxtal percent, condition index parameters, different results were indicative of multicollinearity. (Table 1)

With this, the multivariate technique of main components analysis was used to observe the formation of components and their contributions of parameters for each component, with the intention of listing variable passive exclusion; however, the analysis showed the formation of just one factor, not allowing the exclusion of parameters.

With the identification of multicollinearity and impossibility of reducing independent variables, we adopted the Ridge Regression Estimator analysis given the ability to produce more accurate observations in this condition. ${ }^{24}$ Thus, multicollinearity was controlled (VIF near zero $(p<0.001)$ with estimator $0.92 \mathrm{M}$ to $0.36 \mathrm{~F}$ ). With all assumptions met, prediction models were generated.

Female model $=1.383695+1.047914^{*} 1.531326^{*} \times 1+X 2+X 3+1.582101 *$ $1.394641 * 1.458194 * X 4+X 5+X 6 * 1.564195$

Male model $=2.585927+0.5388566+0.9107263^{*} \times 1 * X 2+X 3+0.9878149$ *1.690163*1.69796*X4+X5+X6*1.605068

Where: $\mathrm{X} 1=$ time for $0-10$ meters, $X 2=$ time for $10-20$ meters, $X 3=$ time for 20-30 meters, $X 4$ = time for 30-40 meters, $X 5=$ time for 40-50 meters, $\mathrm{X} 6$ = time for $50-60$ meters.

Whereas $\mathrm{M}_{\text {validation }}$ and $\mathrm{F}_{\text {validation, }}$ the predictive models presented $\mathrm{EC}$ below $0.001 \mathrm{~s}$ (both sexes), $\mathrm{TE}_{\mathrm{abs}}$ of $0.12 \mathrm{~s}$ and $0.10 \mathrm{~s}$ respectively, and $\mathrm{TE}_{\mathrm{re}}$ of $1.13 \%$ and $0.85 \%$ respectively. (Table 2 )

In these subgroups were also found near perfect correlation coefficients and determination coefficient high values, besides not having statistically significant differences $(p<.001)$ between predicted and criteria values. (Table 2)

Bland-Altman analysis showed high level of agreement between the predicted and criteria values in the subgroups $F_{\text {validation }}$ and $M_{\text {validation }}$

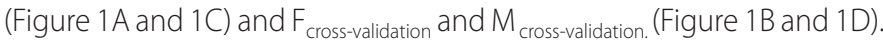

Table 1. Ridge regression analysis results

\begin{tabular}{|c|c|c|c|c|c|c|c|c|c|}
\hline & & VIF & \multicolumn{7}{|c|}{ Eigenvalues of correlations } \\
\hline & & \multirow[b]{2}{*}{ M } & \multicolumn{2}{|c|}{ Eigenvalue } & \multicolumn{2}{|c|}{$\begin{array}{c}\text { Incremental } \\
\text { percent }\end{array}$} & \multicolumn{2}{|c|}{$\begin{array}{c}\text { Condition } \\
\text { index }\end{array}$} & \multirow[b]{2}{*}{$\mathrm{F}$} \\
\hline & & & $\mathrm{F}$ & M & $\mathrm{F}$ & $M$ & $\mathrm{~F}$ & $M$ & \\
\hline \multirow{6}{*}{ 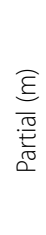 } & 0 to 10 & 1.4 & 2.6 & 5 & 6 & 61 & 75 & 1 & 1 \\
\hline & 10 to 20 & 2.2 & 3.5 & 1 & 1 & 14 & 1 & 4 & 7 \\
\hline & 20 to 30 & 2.5 & 4.5 & 1 & 0 & 9 & 0 & 7 & 15 \\
\hline & 30 to 40 & 4.4 & 6.2 & 0 & 0 & 45 & 0 & 11 & 25 \\
\hline & 40 to 50 & 5.7 & 9.9 & 0 & 0 & 3 & 0 & 18 & 35 \\
\hline & 50 to 60 & 5.0 & 9.1 & 0 & 0 & 3 & 0 & 19 & 54 \\
\hline
\end{tabular}

Table 2. Performance characteristics [mean $( \pm S D)$ ] of the validation $\left(M_{\text {validation }}\right.$ and $\left.F_{\text {validation }}\right)$ and cross-validation groups ( $M_{\text {cross-validation }}$ and $\left.F_{\text {cross-validation }}\right)$.

\begin{tabular}{|c|c|c|c|c|c|c|c|c|c|}
\hline & & Time (s) & CE & $\mathrm{TE}_{\mathrm{abs}}$ & $\mathrm{TE}_{\mathrm{rel}}$ & SEM & $r$ & $\mathrm{R}^{2}$ & $\mathrm{~T}$ \\
\hline \multirow{2}{*}{$M_{\text {validation }}$} & Criterion & $10.95( \pm .45)$ & \multirow{2}{*}{$<0.001$} & \multirow{2}{*}{0.12} & \multirow{2}{*}{1.13} & \multirow{2}{*}{0.02} & \multirow{2}{*}{$0.99^{*}$} & \multirow{2}{*}{0.98} & \multirow{2}{*}{-0.03} \\
\hline & Predict & $10.95( \pm .36)$ & & & & & & & \\
\hline \multirow{2}{*}{$M_{\text {cross-validation }}$} & Criterion & $10.87( \pm .38)$ & \multirow{2}{*}{-0.02} & \multirow{2}{*}{0.10} & \multirow{2}{*}{0.88} & \multirow{2}{*}{0.03} & \multirow{2}{*}{$0.99^{*}$} & \multirow{2}{*}{0.98} & \multirow{2}{*}{0.30} \\
\hline & Predict & $10.89( \pm .31)$ & & & & & & & \\
\hline \multirow{2}{*}{$F_{\text {validation }}$} & Criterion & $11.87( \pm .59)$ & \multirow{2}{*}{$<0.001$} & \multirow{2}{*}{0.10} & \multirow{2}{*}{0.85} & \multirow{2}{*}{0.02} & \multirow{2}{*}{$0.99^{*}$} & \multirow{2}{*}{0.98} & \multirow{2}{*}{-0.02} \\
\hline & Predict & $11.87( \pm .51)$ & & & & & & & \\
\hline \multirow{2}{*}{$F_{\text {cross-validation }}$} & Criterion & $11.84( \pm .33)$ & \multirow{2}{*}{-0.03} & \multirow{2}{*}{0.08} & \multirow{2}{*}{0.64} & \multirow{2}{*}{0.02} & \multirow{2}{*}{$0.98^{*}$} & \multirow{2}{*}{0.96} & \multirow{2}{*}{-0.54} \\
\hline & Predict & $11.85( \pm .31)$ & & & & & & & \\
\hline
\end{tabular}

${ }^{*} p<05$. Pearson linear correlation coeficient $[(r)$ between the measured criteria values and predicted ones] determination coefficient $\left(\mathrm{R}^{2}\right)$, constant error (CE), standard error of measurement (SEM), absolute total error $\left(T E_{a b s}\right)$, total relative error $\left(T E_{r e s}\right)$.

\section{DISCUSSION}

The $60 \mathrm{~m}$ test has been commonly used by coaches and trainers for performance prediction of $100 \mathrm{~m}$ activities, however empirically explaining the embodiment of the present study.

Performance prediction models are promising given that predicted values (10.95 $\pm 0.38 \mathrm{~s}$ and $11.84 \pm 0.55 \mathrm{~s})$ are close to the criteria values $(10.95 \pm 0.45 \mathrm{~s}$ and $11.84 \pm 0.59 \mathrm{~s})$ for $\mathrm{M}_{\text {validation }}$ and $\mathrm{F}_{\text {validation, }}$ respectively, and for presenting extremely low SEM values (0.02s for both sexes), CE (<0.001s for both sexes), $\mathrm{TE}_{\mathrm{abs}}$ of $0.12 \mathrm{~s}$ and $0.10 \mathrm{~s}$ (for $\mathrm{M}_{\text {validation }}$ and $\mathrm{F}_{\text {validation, }}$ respectively) and $\mathrm{TE}_{\mathrm{rel}}$ $1.13 \%$ and $0.85 \%$ (for $M_{\text {validation }}$ and $F_{\text {validation, }}$ respectively). (Table 2 ) These results indicate the accuracy of the model generated in the prediction.

The SEM value of $0.02 \mathrm{~s}$ suggests a range within which the "true value" can be expected considering the error associated ${ }^{20}$. Considering 


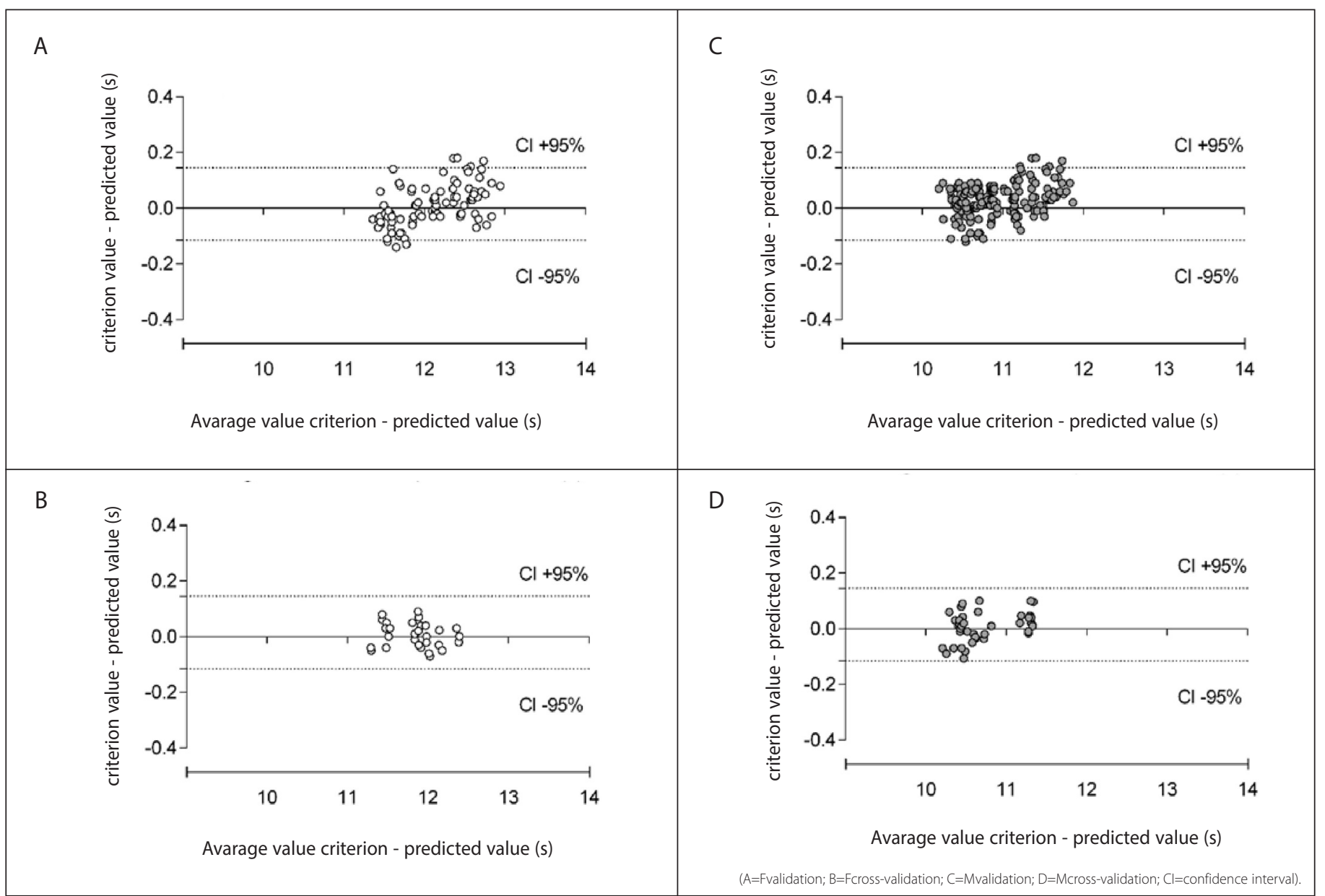

Figure 1. Bland-Altman analysis with criterion value and predicted value in the tests of 100-meter dash.

a hypothetical condition of an athlete completing the distance in $11.20 \mathrm{~s}$, one can say with $0.95 \%$ confidence ( $2 \pm$ SEM) the "true value"for this individual is between $11.24 \mathrm{~s}$ and $11.16 \mathrm{~s}$. Thus, major changes to 0.02 seconds represent real change in performance rather than measurement error.

This approach contributes greatly to coaches who use the tests as performance indicators, since it can be considered a"real" condition of the athlete.

CE lower than $0.001 \mathrm{~s}, \mathrm{TE}_{\mathrm{rel}}$ of $1.13 \%$ and $0.85 \%$ (for $\mathrm{M}_{\text {validation }}$ and $F_{\text {validation, }}$ respectively), correlation coefficients near perfect $(R=.99)^{22}$ and $0.98 \%$ determination, besides absence of differences $(p<.001)$ between the predicted and criteria values indicate that the models present accuracy and validity.

Bland-Altman analysis (Figure 1) confirms this condition given to substantially close agreement observed between criteria and predicted time.

With this, it can be considered that the proposed models are valid for predicting performance in the 100 meters, for both men and women.

Considering the possibility of extrapolating the use of the generated models, knowledge of the responses found in other population was necessary. In this regard, for $\mathrm{M}_{\text {cross-validation }}$ and $\mathrm{F}_{\text {cross-validation }}$ groups, the models application generated predicted values of $10.89 \pm 0.31 \mathrm{~s}$ and $11.85 \pm 0.31 \mathrm{~s}$, respectively, consistent with criteria values $(10.87 \pm 0.38 \mathrm{~s}$ and $11.84 \pm 0.33 \mathrm{~s}$, respectively).

Following the results found for $\mathrm{M}_{\text {validation }}$ and $\mathrm{F}_{\text {validation }}$ groups, SEM values were extremely low $\left(0.02\right.$ and 0.03 s seconds for $M_{\text {validation }}$ and $F_{\text {validation, }}$ respectively), as well as CE (-0.02s and $-0.03 \mathrm{~s}$ for $\mathrm{M}_{\text {validation }}$ and $F_{\text {validation, }}$ respectively), $T E_{\text {abs }}$ of $0.10 \mathrm{~s}$ to $0.80 \mathrm{~s}$ (for $\mathrm{M}_{\text {validation }}$ and $\mathrm{F}_{\text {validation, }}$ respectively) and $\mathrm{TE}_{\mathrm{rel}}$ of $0.88 \%$ and $0.64 \%$ (for $\mathrm{M}_{\text {validation }}$ and $\mathrm{F}_{\text {validation' }}$ respectively). (Table 2)

The correlation and determination coefficients also showed values close to perfect ${ }^{22}\left(.98<r<.99,96 \%<R^{2}<98 \%\right)$ in both subgroups. (Table 2)
These results demonstrate that when generated models were applied in a separate sample, results with low error magnitude were found with high levels of agreement between the predicted and actual values. (Figure 1B and 1D)

Bland-Altman analysis and $\mathrm{M}_{\text {validation }}$ and $\mathrm{F}_{\text {validation }}$ subgroups (Figure $1 \mathrm{~A}$ and $1 \mathrm{C}$ ) also revealed a regression models tendency for producing larger SEM values in lower performance athletes. These results are in agreement with the literature, since when distinct $100 \mathrm{~m}$ paths of national level athletes and runners of world championships were compared, a significant reduction of speed $(p<.05)$ after 60 meters was found in the lower performance athletes. ${ }^{13}$ Thus, higher performance athletes tend to produce a lower change rate in the final stretches of proof than lower performance level ones.

In this scenario, the results suggest models with accepted external validity, given the possibility of applying these models in other samples from runners with accurate response.

Nevertheless, despite having found relevant answer of practical nature, possible limitations on the construction of the proposed models can be found on a proposed relationship basis between the number of predictor variables and the number of observed cases, suggested from 10 cases of data for each predictor model.

Although a very close recommended relationship has been used in this study $\left(12\right.$ cases for each model predictor in $\mathrm{F}_{\text {validation }}$ and 20 cases for each model predictor in $M_{\text {validation }}$ ), this does not compromise the generated model, since it is also recommended that the sample size depends on the effect size that you want to detect. ${ }^{17}$ Whereas it has been proposed to calculate the effect of sample size on research by the equation $k /(n-1)$, being $K$ the number of predictor variables, $n$ the number of observed cases, ${ }^{5}$ in this study, there was obtained an effect 
size of 0.05 and 0.03 for $F_{\text {validation }}$ and $M_{\text {validation, }}$ respectively. Therefore, it was classified as very small or insubstantial magnitude of effect, ${ }^{11}$ signaling that the sample size did not influence the modeling equations, and so, the prediction of the desired performance.

\section{CONCLUSION}

Results suggest models with external validity, given the possibility of application to other sprinter samples with accurate response when purpose is to predict tests of $100 \mathrm{~m}$ from parameters obtained in the distance of $60 \mathrm{~m}$. This extrapolation possibility is justified by reduced errors in predicted values with no significant differences between the criteria and predicted value, high levels of agreement, Pearson product-moment correlation coeficient and high coefficients of determination values.

All authors declare no potential conflict of interest related to this article

AUTHORS' CONTRIBUTIONS: Each author made significant individual contributions to this manuscript. RMA (0000-0002-4816-5635)*: substantial contribution to the conception or design of the work; acquisition, analysis or interpretation of data for the work; drafting of the work; final approval of the version of the manuscript to be published. AJFJr (00000002-6635-8019)*: substantial contribution to the conception or design of the work; critical revision of its intellectual content; final approval of the version of the manuscript to be published. ACA (0000-0002-2527-2163)*: substantial contribution to the conception or design of the work, interpretation of data for the work; critical revision of its intellectual content; final approval of the version of the manuscript to be published. JCS (0000-0002-3646-3387)*: substantial contribution to the conception or design of the work; interpretation of data for the work; critical revision of its intellectual content; final approval of the version of the manuscript to be published. *ORCID (Open Researcher and Contributor ID).

\section{REFERENCES}

1. Krzysztof M, Mero A. A kinematics analysis of three best $100 \mathrm{~m}$ performances ever. J Hum Kinet. 2013;36:149-60

2. Mackala K. Optimisation of performance through kinematic analysis of the different phases of the 100 metres. NSA. 2007;22(2):7-16

3. Okkonen O, Hakkinen K. Biomechanical comparison between sprint start, sled pulling, and selected squat-type exercises. J Strength Cond Res. 2013;27(10):2662-73.

4. Morin JB, Jeannin T, Chevallier B, Belli A. Spring-mass model characteristics during sprint running: Correlation with performance and fatigue-induced changes. Int I Sports Med. 2006;27(2):158-65.

5. Taylor MJ, Beneke R. Spring mass characteristics of the fastest men on Earth. Int J Sports Med. 2012;33(8):667-70

6. Morin JB, Tomazin K, Edouard P, Millet GY. Changes in running mechanics and spring-mass behavior induced by a mountain ultra-marathon race. J Biomech. 2011;44(6):1104-7.

7. Weyand PG, Sternlight DB, Bellizzi MJ, Wright S. Faster top running speeds are achieved with greater ground forces not more rapid leg movements. J Appl Physiol (1985). 2000;89(5):1991-9.

8. Ettema GJ. Muscle efficiency: The controversial role of elasticity and mechanical energy conversion in stretch-shortening cycles. Eur J Appl Physiol. 2001;85(5):457-65

9. Fletcher JR, Pfister TR, Macintosh BR. Energy cost of running and achilles tendon stiffness in man and woman trained runners. Physiol Rep. 2013;1(7):e00178.

10. Fourchet F, Girard O, Kelly L, Horobeanu C, Millet GP. Changes in leg spring behaviour, plantar loading and foot mobility magnitude induced by an exhaustive treadmill run in adolescent middle-distance runners. J Sci Med Sport. 2015;18(2):199-203.

11. Smith D, Telford R, Peltola E, Tumilty D. Protocols for the physiological assessment of high-performance runners. In: Gore C. Physiological Tests for Elite Athletes. Champaign, Illinois: Human Kinetics; 2000: p.334-44.
12. Thomas J, Nelson J, Silverman S. Research methods in physical activity 6th ed. Champaign, Illinois: Human Kinetics; 2010

13. Atkinson G, Nevill AM. Statistical methods for assessing measurement error (reliability) in variables relevant to sports medicine. Sports Med. 1998;26(4):217-38.

14. Murphy AJ, Lockie RG, Coutts AJ. Kinematic determinants of early acceleration in field sport athletes. J Sports Sci Med. 2003;2(4):144-50

15. Graubner R, Nixdorf E. Biomechanical analysis of the sprint and hurdles events at the 2009 IAAF world championships in athletics. New Stud Athlet. 2011;26(1/2):19-53.

16. Cunha JVA, Coelho AC. Regressão Linear Multipla. In: Corrar L, Paulo E, Dias Filho JM. Análise multivariada para os cursos de Administração, Ciências Contábeis e Economia. São Paulo: Atlas; 2009; p.131-231.

17. Field A. Discovering statistics using SPSS. 2rd ed. Thousand Oaks, California: SAGE Publications; 2005.

18. Savin NE, White KJ. The Durbin-Watson test for serial correlation with extreme sample sizes or many regressors. Econometrica. 1977;45(8):1989-96.

19. Hair JF, BlackWC, Babin BJ, Anderson RE, Tatham RL. Análise Multivariada de Dados. 6. ed. Porto Alegre: Bookman; 2009.

20. Hoerl AE, Kennard RW. Ridge regression: Biased estimation for nonorthogonal problems. Technometrics. 1970;12(1):55-67.

21. Perini TA, Oliveira GLd, Ornellas JdS, Oliveira FPd. Technical error of measurement in anthropometry. Rev Bras Med Esporte. 2005;1 (1):86-90.

22. Hopkins WG. A scale of magnitudes for effect statistic. 2002 [Access in 2014 dec 1]. Available in: http:// www.sportsci.org/resource/stats/index.html.

23. Bland JM, Altman DG. Statistical methods for assessing agreement between two methods of clinical measurement. Lancet. 1986;1(8476):307-10

24. Neter J, Wasserman W, Kutner MH, Nachtshelm CJ. Applied linear regression models. 3rd ed. Chicago, Illinois: McGraw-Hill; 1996. 